\title{
Strategi Komunikasi Organisasi Suka Duka Kerta Warga dalam Mewujudkan Toleransi Umat Hindu-Kristen di Desa Adat Piling Kecamatan Penebel Kabupaten \\ Tabanan
}

I Made Ananda Kusuma Adnyana ${ }^{1}$, I Wayan Sukabawa², I Ketut Wardana Yasa ${ }^{3}$

123 Institut Hindu Dharma Negeri Denpasar

Abstract

Keywords
In an effort to maintain harmony between religions, the people of Adat Piling Village have formed an organization called the Joy and Grief Society, whose members consist of Hindus and Christians in the Indigenous Village of Piling.

Based on this background there are several issues raised, namely: 1) How do the communication strategies of the Community Grieving Society in realizing the tolerance of Hindus and Christians in the Adat Piling Village Penebel District of Tabanan Regency? in realizing tolerance between Hindus and Christians in Adat Piling Village Penebel District Tabanan Regency? 3) What is the impact of the implementation of the communication strategy of the Grieving Society and Residents towards Hindus and Christians in the Adat Piling Village Penebel District Tabanan Regency.

The results of the analysis obtained from this study are: 1) Communication strategies of Organizational Joy and Grief Residents in realizing tolerance between Hindus and Christians in the Indigenous Village of Piling using five types of communication, namely: a) verbal communication, b) non verbal communication, c) interpersonal communication, d) persuasive communication, and e) group communication. 2) The obstacles that exist in the implementation of the communication strategies of the People's Sorrowful Organizations are in the form of physical barriers, differences in mindset, social factors. 3) The impact arising from the implementation of communication strategies of the Community Grieving Society on Hindus and Christians in the Piling Traditional Village includes cognitive impacts, affective impacts, behavioral impacts, and social impacts.

Communication Strategy, Christian-Hindu Relationship, Suka-Duka

\footnotetext{
1 ananda_kusumaadnyana@gmail.com

${ }^{2}$ wayan_sukabawa@ihdn.ac.id

3 wardana_yasa@ihdn.ac.id
} 


\section{PENDAHULUAN}

Manusia merupakan mahluk sosial yang membutuhkan manusia lain untuk mempertahankan kelangsungan hidupnya. Artinya manusia tidak dapat hidup sendiri tanpa manusia lainnya, selalu ingin hidup berkawan, membentuk sistem sosial guna memenuhi kebutuhan hidupnya. Untuk memenuhi kebutuhan hidupnya manusia harus berinteraksi dengan manusia lainnya. Ini konsekuensi kedudukan manusia sebagai mahluk sosial. Interaksi manusia dengan manusia lainnya membutuhkan komunikasi. Pada hakikatnya komunikasi merupakan tindakan manusia sebagai pemenuhan kebutuhan untuk berinteraksi dengan orang lain (communication hunger) (Suranto, 2010 : 44). Organisasi adalah salah satu cara manusia untuk berinteraksi dengan sesamanya. Melalui sebuah organisasi manusia dapat saling berhubungan guna memenuhi kebutuhan hidupnya, baik kebutuhan fisik, psikologis dan sosial.

Hasibuan (2011 : 120) menjelaskan, organisasi secara sederhana dapat diartikan sebagai suatu kesatuan yang merupakan wadah atau sarana untuk mencapai berbagai tujuan atau sasaran. Organisasi memiliki banyak komponen yang melandasi, diantaranya banyak orang, tata hubungan kerja, spesialis pekerjaan dan kesadaran rasional dari anggota sesuai kemampuan mereka dan spesialisnya masing-masing.

Organisasi digunakan sebagai dasar manusia dalam hidup berkelompok dan sebagai wadah salingbertukar pemikiran untuk bekerjasama guna mencapai tujuan yang diinginkan. Organisasi Suka Duka Kerta Warga merupakan salah satu contoh organisasi yang digunakan oleh masyarakat Desa Adat Piling sebagai wadah untuk mempersatukan dua budaya yang berbeda, guna mewujudkan hubungan yang harmonis antara umat Hindu-Kristen yang terdapat di Desa Adat Piling.

Desa Adat Piling merupakan sebuah desa yang terletak di Kecamatan Penebel Kabupaten Tabanan yang memiliki penduduk heterogen, terdiri dari Umat Hindu dan Umat Kristen. Keberagaman budaya yang terdapat pada masingmasing agama mengharuskan masyarakat di desa tersebut membentuk sebuah organisasi guna untuk mempersatukan perbedaan diantara dua kebudayaan yang berbeda. Masyarakat Desa Adat Piling membentuk sebuah organisasi yang bernama Organisasi Suka Duka Kerta Warga yang bertujuan untuk menciptakan hubungan yang harmonis serta rasa toleransi diantara umat Hindu dan Kristen yang terdapat di Desa Adat Piling.

\section{METODE}

Jenis dan pendekatan dalam penelitian ini mempergunakan metode kualitatif.Lokasi penelitian bertempat di Desa Adat Piling Kecamatan Penebel Kabupaten Tabanan.Penentuan informan mempergunakan teknis purposive sampling.Jenis dan sumber data yang dipergunakan adalah kualitatif dan sumber data yang dipergunakan berupa data primer dan data sekunder. Instrumen Penelitian ini menggunakan instrumen berupa pedoman wawancara, camera digital, telepon genggam dan catatan lapangan. Inti Instrumen penelitian ini adalah peneliti itu sendiri. Teknik pengumpulan data yang dipergunakan seperti: observasi, wawancara, studi kepustakaan. Teknik analisis data dilakukan dengan beberapa tahapan seperti: reduksi, penyajian data, 
dan penarikan kesimpulan. Teknik penyajian hasil penelitian dilakukan dengan metode deskriptif.

\section{HASIL PENELITIAN}

\section{Strategi Komunikasi Organisasi Suka Duka Kerta Warga}

Strategi komunikasi adalah paduan dari perencanaan komunikasi (communication planning) dan manajemen komunikasi (communication management) untuk mencapai suatu tujuan. Untuk mencapai tujuan tersebut strategi komunikasi harus dapat menunjukan bagaimana operasionalnya secara taktis harus dilakukan, dalam arti kata bahwa pendekatan (approach) bisa berbeda sewaktu-waktu bergantung pada situasi dan kondisi (Effendy, 2000 : 301).

Organisasi Suka Duka Kerta Warga dalam menentukan strategi komunikasi yang digunakan dalam mewejudkan toleransi antar umat Hindu-Kriten terlebih daulu mengetahui komponen-komponen komunikasi yang ada pada organisasi dan mayarakat, sehingga strategi komunikasi yang digunakan tepat sasaran dan dapat mewujudkan toleransi antar umat beragama yang ada di Desa Adat Piling. Adapun komponen-komponen tersebut adalah Who? (Siapakah komunikatornya?), Says What? (Pesan apa yang ditanyakannya?), In Which Channel? (media apa yang digunakannya?), To Whom? (Siapa komunikannya?), With What Effect? (Efek apa yang diharapkan?).

Komponen tersebut menghasilkan sebuah proses komunikasi. Adapun proses komunikasi yang dilakukan oleh Organisasi Suka Duka Kerta Warga di Desa Adat Piling ialah:

1. Komunikasi verbal
Komunikasi verbal adalah komunikasi yang menggunakan kata-kata, lisan, maupun tertulis. Komunikasi ini paling banyak digunakan dalam hubungan antar keidupan. Melalui kata-kata, mengungkapkan perasaan, emosi, pemikiran, gagasan atau maksud. Menyampaikan data, fakta dan informasi serta menjelaskannya, saling bertukar perasaan dan pemikiran, saling berdebat dan bertengkar. Komunikasi verbal memegang peranan yang sangat penting (Hardjana, 2003 : 22).

Organisasi Suka Duka Kerta Wargadalam upaya mewujudkan toleransi antar umat Hindu dan umat Kristen yang ada di Desa Adat Piling, melakukan sebuah komunikasi verbal. Komunikasi ini dilakukan guna adanya interaksi diantara umat Hindu dan umat Kristen sehingga diaharapkan terjalinnya sebuah hubungan yang baik diantara kedua umat beragama yang ada di Desa Adat Piling. Komunikasi verbal tersebut salah satunya terdapat dalam sebuah tradisi yang dikenal dengan tradisi Metulungan. 2. Komunikasi Nonverbal

Komunikasi nonverbalmerupakan komunikasi yang pesannya dikemas dalam bentuk nonerbal, tanpa kata-kata. Berkomunikasi hampir secara otomatis komunikasi nonverbal ikut terpakai. Komunikasi nonverbal bersifat tetap dan selalu ada serta komunikasi nonverbal lebih jujur mengungkapkan hal yang mau diungkapkan karena spontan (Hardjana, 2003 : 26).

Bentuk komunikasi nonverbal dalam strategi komunikasi Organisasi Suka Duka Kerta Warga berupa bahasa tubuh, tanda dan tindakan atau perbuatan. Bahasa tubuh yang digunakan berupa raut wajah, gerak kepala, gerak tangan. Organisasi Suka Duka menggunakan tanda, gerakan tangan dan gerakan 
kepala sebagai pengganti kata-kata. Tindakan atau perbuatan sebetulnya tidak khusus dimaksudkan untuk mengganti kata-kata, tetapi dapat menghantarkan makna misalnya pada saat Suka Duka melaksanakan sebuah kegiatan sosial keagamaan sala satu anggota mengatakan baik dengan mengangkat jempol setelah diberikan tugas oleh ketua Suka Duka.

\section{Komunikasi Persuasif}

Persuasif adalah kegiatan psikologis dalam usaha mempengaruhi pendapat, sikap dan prilaku orang atau orang banyak. Adapun upaya mempengaruhi pendapat, sikap, sifat dan prilaku itu bisa dilakukan dengan beragam cara. Persuasi mempengaruhi orang dengan komunikasi dalam artian interaksi antar manusia yang menggunakan argumentasi psikologis. Pada hakikatnya semua orang bergumul dalam memenuhi kebutuhan pokoknya yang terkait dengan kesehatan, keamanan baik lahiria maupun batiniah, itu semua merupakan dasar-dasar bagi orang untuk berfikir, berbuat dan bertingkahlaku disamping faktor-faktor keinginan (want and desira) serta dorongan dasar (drive) (Suandang, 2009 : 159).

Faktor perhatian sangat berpengaruh bagi strategi komunikasi Organisasi Suka Duka Kerta Warga terhadap umat Hindu dan umat Kristen yang ada di Desa Adat Piling. Usaha dalam menimbulkan perhatian umat Hindu dan umat Kristen terhadap strategi komunikasi guna mewujudkan toleransi antar umat beragama, organisasi Suka Duka melibatkan seluruh masyarakat di Desa Adat Piling sehingga tejadi proses komunikasi dan interaksi dari umat Hindu dan umat Kristen. Masyarakat baik umat Hindu maupun Kristen diajak untuk saling bergotong royong dalam melaksanakan sebuah kegiatan, sehingga diharapkan dapat menumbukan rasa kebersamaan dan toleransi antar umat beragama.

4. Komunikasi Kelompok

Komunikasi kelompok merupakan komunikasi antar satu kelompok tertentu dengan kelompok yang lainnya. Komunikasi kelompok adalah salah satu strategi komunikasi digunakan dalam kegiatan kemasyarakatan untuk mencapai kesuksesan. Hal ini tidak lepas dari kehidupan bermasyarakat adalah kehidupan berkelompok (Kharimah, dkk, 2010 : 9).

Organisasi Suka Duka Kerta Warga menerapkan komunikasi kelompok dalam penerapan strategi komunikasi yang dilakukan guna mewujudkan toleransi umat Hindu-Kristen di Desa Adat Piling. Komunikasi kelompok yang dilaksanakan adalah penyampaian pesan dari pengurus Suka Duka kepada seluruh masyarakat baik umat Hindu maupun umat Kristen. Pesan yang dimaksud merupakan ajakan untuk bergotong royong dan saling tolong menolong dalam melakanakan sebuah kegiatan sosial keagamaan di lingkungan Desa Adat Piling. Seluruh anggota Organisasi Suka Duka dibagi menjadi sembilan kelompok yang disebut dengan regu. Masing-masing regu terdiri dari 20 sampai 25 orang yang terdiri dari umat Hindu dan umat Kristen. Pelaksanaan kegiatan sosial keagamaan dilakukan dengan cara bergotong royong yang diebut dengan nanggap. Anggota Suka Dukaakan diberikan tugas dan dibagi pada masing-masing regu, setelah itu regu akan saling bergantian dalam melakanakan tugas seuai dengan jadwal nanggap yang telah disepakati dari hasil meremug yang dilakukan sebelum 
melaksanakan kegiatan sosial keagamaan.

\section{Hambatan Strategi Komunikasi Organisasi Suka Duka Kerta Warga}

Kendala atau hambatan dapat diartikan sebagai halangan atau rintangan yang dialami. Hambatan komunikasi dikenal pula sebagai gangguan (semantik atau mekanik), gangguan ini masih termasuk kedalam hambatan komunikasi. Efektivitas komunikasi salah satunya akan dipengaruhi oleh seberapa besar kendala atau hambatan yang dialami (Onong, 2007).

Hambatan yang terjadi dalam strategi komunikasi Organisasi Suka Duka salah satunya adalah faktor fisik yaitu jarak diantara anggota Suka Duka.Jarak antara anggota yang bejauhan menyebabkan terhambatnya pengiriman informasi yang dilakukan oleh pengurusSuka Duka. Perbedaan pola pikir dan perepsi dari anggota juga merupakan hambatan bagi strategi komunikasi Organisasi Suka Duka dalam mewujudkan toleransi umat Hindu dan Kristen yang ada di Desa Adat Piling. Oraganisasi Suka Duka terdiri dari anggota yang memiliki latar belakang budaya yang berbeda, sehingga masingmasing anggota memiliki pengetahuan dan pola pikir yang berbeda. Perbedaan pola pikir tersebut menghasilkan sebuah sudut pandang yang berbeda-beda dari masing-maing anggota. Hal tersebut dapat menghambatan pelaksanaan strategi komunikasi yang dilakukan oleh organisasi Suka Duka Kerta Warga. Perbedaan pola pikir seseorang disebabkan oleh bedanya jumlah sudut pandang yang dijadikan dasar, landasan atau alasan. Banyaknya sudut pandang seseorang untuk berpikir dipengaruhi oleh emosi, pengetahuan dan pengalaman.

\section{Dampak Strategi Komunikasi Organisasi Suka Duka Kerta Warga}

Suatu proses yang dilakukan tentu menghasilkan suatu efek. Sebagai suatu proses, komunikasi menghasilkan efek atau dampak bagi komunikator maupun komunikan. Dampak atau efek komunikasi dapat berupa perubahan sikap, perilaku, atau persepsi. Melvin L DeFleur (Rohim 2012 : 182-183) menjelakan ada tiga dampak komunikasi yaitu: kognitif (pengetahuan), afektif (sikap), dan behavioral atau psikomotorik (tindakan/prilaku).

Dampak kognitif merupakan dampak yang berupa peningkatan pengetahuan. Berkaitan dengan strategi komunikasi organisasi Suka Duka Kerta Warga di Desa Adat Piling Kecamatan Penebel Kabupaten Tabanan dampak kognitif yang terjadi yaitu dapat meningkatkan pola pikir anggota organisasi dan masyarakat serta merubah pemikiran masyarakat dalam bentuk pengetahuan, pendapat, dan sudut pandang.

Selain dampak kognitif dalam stratergi komunikasi organisasi Suka Duka Kerta Warga di Desa Adat Piling Kecamatan Penebel kabupaten Tabanan terdapat pula dampak afektif.Dampak afektif merupakan dampak yang yang berkaitan dengan perubahan sikap, pemikiran dan persepsi.Organisasi Suka Duka Kerta Warga dalam melaksanakan sebuah kegiatana melibatkan maseluruh anggota organisasi, baik dari umat Hindu maupun umat Kristen. Dengan melibatkan seluruh anggota organisasi maka akan membentuk sebuah sikap yang berbeda-beda dari setiap individu anggota organisasi.

Dampak komunikasi yang diuraikan oleh DeFleur diatas merupakan dampak yang saling berkaitan. Ketika pengetahuan seseorang meningkat dari hasil sebuah 
proses komunikasi, maka seiring dengan hal terebut pemikiran, sikap, dan persepsi seseorang pun dapat berubah. Perubahan pemikiran, sikap, dan persepsi memicu seseorang melakukan tindakan atau perilaku yang sesuai dengan peningkatan pengetahuan dan sikap atau pemikirannya dari keseluruhan dampak komunikasi tersebut. Dampak yang paling berpengaruh dan merupakan alat ukur keberhasilan sebuah proses komunikasi adalah dampak behavioral. Hal ini dikarenakan perubahan perilaku merupakan perubahan yang paling mudah diamati, sehingga keberhasilan sebuah proses komunikasi dapat diamati. Dampak behavioral tersebut dapat berupa banyak hal, misalnya pelestarian budaya, dampak sosial, dampak religius dan lain-lain sesuai dengan proses komunikasi yang dilakukan.

Contoh dampak behavioral yang dari strategi komunikasi yang dilakukan oranisasi Suka Duka Kerta Warga di Desa Adat Piling adalah adanya tradisi Metulungan.Metulungan dilakukan pada saat umat Hindu maupun umat Kristen menyelenggarakan sebuah kegiatan soial keagamaan. Umat Hindu dan umat Kristen di Desa Adat Piling melaksanakan tradisi metulungan dengan rasa tulus dan tanpa adanya rasa terpaksa pada masing-masing umat bergama tersebut.Metulungan dilakukan guna meningkatkan rasa persaudaraan diantara umat Hindu dan umat Kristen dengan cara saling tolong menolong dalam melaksanakan sebuah kegiatan sosial keagamaan.

\section{KESIMPULAN}

Organisasi Suka Duka Kerta Warga dalam menentukan strategi komunikasi yang digunakan dalam mewejudkan toleransi antar umat Hindu-Kriten terlebih dahulu mengetahui komponen-komponen komunikasi yang ada pada organisasi dan masyarakat, sehingga strategi komunikasi yang digunakan tepat sasaran dan dapat mewujudkan toleransi antar umat beragama yang ada di Desa Adat Piling. Terdapat lima komponen yang digunakan dalam strategi komunikasi organisasi Suka Dukayaitu : a) Who? (Siapakah komunikatornya?), b) Says What? (Pesan apa yang ditanyakannya?), c) In Which Channel? (media apa yang digunakannya?), d) With What Effect? (Efek apa yang diharapkan?), dan e) To Whom? (Siapa komunikannya?). Organisasi Suka Duka Kerta Warga dalam mewujudkan toleransi antar umat hindu dan umat kristen di Desa Adat Piling menggunakan lima jenis strategi komunikasi yaitu : a) Komunikasi Verbal, b) Komunikasi Non Verbal, c) Komunikasi Interpersonal, d) Komunikasi Persuasif, dan e) Komunikasi Kelompok.

Hambatan yang dialami oleh organisasi Suka Duka Kerta Warga dalam mewujudkan toleransi antar umat beragama yang ada di Desa Adat Piling yaitu, hambatan yang muncul karena faktor fisik yaitu jarak antara anggota Suka Duka, faktor pemahaman yang menjadi hambatan dalam menyamakan persepsi antara umat hindu dan umat kriten dan faktor lingkungan sosial dalam menumbuhkan dan menjaga hubungan baik antar umat beragama yang ada di Desa Adat Piling.

Dampak yang ditimbulkan dari strategi komunikasi yang dilakukan oleh organisasi Suka Duka Kerta Warga terbagi menjadi empat yaitu : a) Dampak Kognitif, menupakan dampak yang dapat meningkatkan pola pikir anggota 
organisasi dan masyarakat serta merubah pemikiran masyarakat dalam bentuk pengetahuan, pendapat, dan sudut pandang, b) Dampak Afektif, merupakan dampak yang yang berkaitan dengan perubahan sikap, pemikiran dan persepsi dari anggota dan mayarakat di Desa Adat Piling, c) Dampak Behavioral, merupakan dampak pada perubahan perilaku misalnya seperti adanya pelestarian tradisi metulungan pada umat Hindu-Kristen di Desa Adat Piling.

\section{DAFTAR PUSTAKA}

Effendy, Onong Uchjana. 2003. IImu, Teori dan Filsafat Komunikasi. Bandung : Citra Aditya Bakti

Hardjana, M Agus. 2003. Komunikasi Intrapersonal \& Interpersonal. Yogyakarta : Kanisius.

Hasibuan, Malayu S.P. 2011. Manajemen Sumber Daya Manusia. Jakarta : Bumi Aksara.

Karimah, Kismianti El, Dkk. 2010. Filsafat dan Etika Komunikasi. Bandung : Wijaya Padjajaran.

Suranto, AW . 2010. Komunikasi Sosial Budaya. Yogyakarta: Graha IImu

Rohim, Syaiful. 2009. Teori Komunikasi : Perspektif, Ragam, \& Aplikasi. Jakarta : Rineka Cipta. 